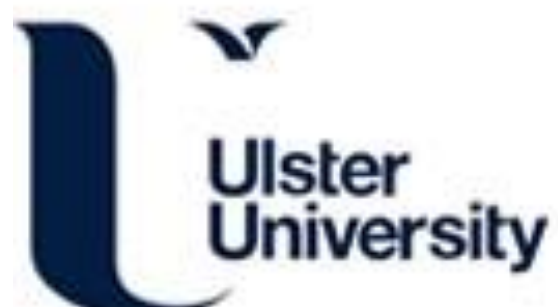

Studying the relationship between vegetation and physico-chemical properties of soil, case study

Reyhan, M. K., \& Amiraslani, F. (2006). Studying the relationship between vegetation and physico-chemical properties of soil, case study: Tabas region, Iran. Pakistan Journal of Nutrition, 5(2), 169-171. https://doi.org/10.3923/pjn.2006.169.171

Link to publication record in Ulster University Research Portal

\section{Published in:}

Pakistan Journal of Nutrition

Publication Status:

Published (in print/issue): 01/01/2006

DOI:

10.3923/pjn.2006.169.171

\section{Document Version}

Publisher's PDF, also known as Version of record

\section{General rights}

Copyright for the publications made accessible via Ulster University's Research Portal is retained by the author(s) and / or other copyright owners and it is a condition of accessing these publications that users recognise and abide by the legal requirements associated with these rights.

\section{Take down policy}

The Research Portal is Ulster University's institutional repository that provides access to Ulster's research outputs. Every effort has been made to ensure that content in the Research Portal does not infringe any person's rights, or applicable UK laws. If you discover content in the Research Portal that you believe breaches copyright or violates any law, please contact pure-support@ulster.ac.uk. 


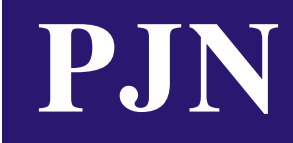

ISSN 1680-5194

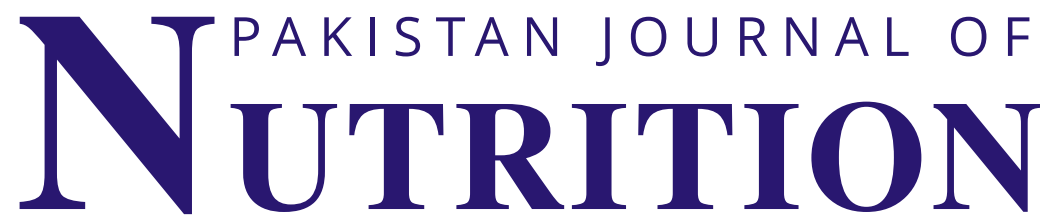

ANSI迫e佔

308 Lasani Town, Sargodha Road, Faisalabad - Pakistan Mob: +92 3003008585 , Fax: +92 418815544

E-mail: editorpjn@gmail.com 
Pakistan Journal of Nutrition 5 (2): 169-171, 2006

ISSN 1680-5194

(C) Asian Network for Scientific Information, 2006

\title{
Studying the Relationship Between Vegetation and Physico-Chemical Properties of Soil, Case Study: Tabas Region, Iran
}

\author{
M.K. Reyhan and F. Amiraslani \\ International Research Center for Living with Desert, University of Tehran, Iran
}

\begin{abstract}
In order to study the relationship between vegetation and physico-chemical properties of soil of the margins of Tabas Kavir (salty desert), vegetation and soil components were surveyed. Regarding to the soil and vegetation distribution and land use in this region, four distinct areas were selected and classified covering all factors. Then, based on different vegetation cover percentage, the minimum plots necessary for validating statistical calculations were assessed. In this case, the plots equal to two fold of assessed value for maximum vegetation cover percentage, i.e 310 spots, were randomly and systematically selected and sampled. According to the observations and based on soil properties in each sampling spots, statistical calculations were done using linear regression to determine the relationship between the distribution of species and soil properties including $\mathrm{CaSO}_{4}, \mathrm{CaCO}_{3}$, gravel percentage, $\mathrm{pH}$ and $\mathrm{EC}$. The best equation was then selected among the 11 suggested equations. This case studied also focused on the some soil factors as variables and their effects on the growth of some plant species (Seidlitzia rosmarinus, Haloxylon aphylum, Alhagi camelorum, Tamarix sp, Prosopis srephaniana, Artemisia siberi, Salsola spp). Generally, in other similar areas like Tabas, these plant species are recommended which show resistant behaviors to such harsh conditions. More efforts should be done to realize other aspects of relationship between soil factors and plants, especially in dry lands.
\end{abstract}

Key words: Land use, vegetation, soil properties

\section{Introduction}

All factors existing in an ecosystem interact on each other and the result is things can be seen in it. In order to introduce an alien plant species to an ecosystem, especially desert ecosystems which are very tender, care must be taken. This process should be carried out based on information of all factors influencing ecosystem and the effects of each existing factor on it (Pourmirza, 1994).

Soil as a stable and renewable resource is a foundation of organisms' survival. It is considered as a part of an ecosystem, having specific properties and varying from one region to another. Some of these properties including the percentage of gypsum, soil saturation percentage, soil acidity and soil salinity affect vegetation cover in an ecosystem (Zarinkafsh, 1987). Hence, the effects of each factor on existing plant species must be recognized and the results must be utilized in rehabilitation activities.

In this study, the relationship between vegetation and the properties of soil in one of the desertified areas of central part of Iran was assessed.

\section{Materials and Methods}

The studied region is located between 5642 to $7542 \mathrm{E}$ and 3317 to $3345 \mathrm{~N}$. Topography maps with 1:50000 scale as basic maps, aerial photo with $1: 50000$ scale of the year 1963 and TM satellite images with 1:100000 scale were used to separate land units, determine land boundaries and working units in the studied area. The soil studies of area were done using mentioned images, field survey, soil profiles and soil sample analysis. Therefore, soil map, lands' capacity classification map, soil salinity map and land use map were prepared. Some of climatic data of Tabas and adjacent meteorological stations were used to identify the climate of area, moisture and thermal regimes.

The vegetation cover was mapped using aerial photos, TM satellite images and field survey. In order to prepare lands' capacity classification map, soil salinity map, land use map and vegetation cover map, four regions were selected and plotted in $500 \mathrm{~m}^{*} 500 \mathrm{~m}$ dimension based on maps. These regions cover all plant types and soils (Tehranian, 1980). Then, the required samples for each plant species were evaluated based on vegetation cover percentage which are valid on $95 \%$ level and probability +3 . The plots equal to two fold of assessed value for maximum vegetation cover percentage, i.e. 310 spots, were randomly and systematically selected and sampled. In this case, plant species in each plot were harvested and soil properties were tested through sampling.

\section{Results and Discussion}

Different plant species (Table 1) were used in this study. The results were analyzed using SPSS computer software. The calculations were multi-variable regression in which the number of plants was 
Reyhan and Amiraslani: Vegetation and Physico-Chemical Properties of Soil

Table 1: The statistical results of independent variable effect on existing species in margin of Tabas Desert

\begin{tabular}{llllllllc}
\hline $\begin{array}{l}\text { Dependant } \\
\text { Variable }\end{array}$ & $\begin{array}{l}\text { Independent } \\
\text { variable }\end{array}$ & $\mathrm{CaCO}_{3} \%$ & $\mathrm{CaSO}_{4} \%$ & $\mathrm{EC}$ & GRAS & GRAT & pH & $\begin{array}{c}\text { Soil } \\
\text { Saturation }\end{array}$ \\
\hline Seidlitzia & $\mathrm{BETA}$ & 0.192186 & -0.219675 & 0.023377 & -0.070347 & 0.039520 & 0.340813 & 0.214560 \\
rosmarinus & $\mathrm{T}$ & 2.335 & -3.618 & 0.293 & -0.566 & 0.324 & 5.994 & -0.022 \\
Haloxylon & $\mathrm{BETA}$ & 0.215631 & 0.128942 & -0.150007 & -0.410181 & 0.659907 & -0.196581 & 0.235050 \\
aphylum & $\mathrm{T}$ & 2.511 & 2.035 & -1.804 & -3.162 & 5.180 & -3.0314 & 3.173 \\
Alhagi & BETA & 0.022576 & 0.387618 & 0.119863 & 0.185335 & -0.221055 & 0.046765 & -0.024025 \\
camelorum & $\mathrm{T}$ & 0.245 & 5.703 & 1.347 & 1.334 & -1.623 & 0.733 & -0.304 \\
Tamrix sp. & BETA & -0.019130 & 0.67837 & 0.176383 & -0.009898 & 0.010371 & -0.076471 & -0.158112 \\
& $\mathrm{~T}$ & -0.197 & 0.948 & 1.877 & -0.068 & 0.072 & -1.141 & -1.889 \\
Prosopis & BETA & 0.236876 & 0.671749 & 0.273128 & 0.309660 & -0.243599 & 0.325431 & 0.043952 \\
srephaniaca & T & 3.156 & 12.131 & 3.758 & 2.731 & -2.188 & 6.276 & 0.679 \\
Artemisia & BETA & 0.056229 & 0.090614 & 0.076607 & 0.344955 & 0.163768 & 1.036176 & 0.208053 \\
siberia & T & 0.647 & 0.414 & 0.911 & 2.629 & 1.504 & 0.603 & 2.776 \\
Salsola spp. & BETA & 0.319389 & -0.004363 & -0.008001 & 0.149693 & -0.1133718 & 0.130197 & 0.157912 \\
& T & 3.401 & 0.063 & 0.088 & 1.055 & -0.960 & 2.007 & 1.949 \\
\hline
\end{tabular}

considered as dependent variable and parameters like gypsum percentage, lime percentage, gravel percentage, soil saturation percentage, soil acidity and soil salinity as independent variables (Zali and Jafari, 1986).

Since the various variables have dispersions, standardized variables were used in this research. In order to convert variables to standardized ones, Z Scale was used. Since $Z$ Scale is used instead of real variables, computer will provide us BETA instead of $B$. However, to recognize the variable having the most roles in identifying dependent variable variance (Khajeh, 1995), BETA rates were compared. Each has a higher rate, having the more role and weight on dependant variable (Abrishami, 1996). The data have been shown in Table 1.

Study reveals that independent variables including soil acidity, gypsum percentage, soil saturation, gravel percentage and soil salinity have lesser effect on Seidlitzia rosmarinus due to have lesser BETA, respectively. Since the effects of soil surface and subsurface gravel percentage and soil salinity were not significant at $95 \%$ level, they were not considered. Hence, soil salinity, gypsum percentage, soil saturation and soil lime percentage have the lesser effect on the distribution of this plant, respectively. It is suggested these factors to be considered for future cultivation.

The independent variables including soil surface gravel percentage, soil saturation, soil lime percentage, soil acidity, soil salinity and gypsum percentage have lesser effect on Haloxylon aphylum due to have lesser BETA, respectively. Since soil salinity was not significant at $95 \%$ level, it was not considered. Hence, soil surface and subsurface gravel percentage, soil saturation, soil lime percentage, soil acidity, soil salinity and gypsum percentage have the lesser effect on the distribution of this plant, respectively. It is suggested these factors to be considered for future cultivation. Study also reveals that independent variables including gypsum percentage, soil surface gravel percentage, soil subsurface gravel percentage, soil acidity, soil saturation and soil lime percentage have lesser effect on Alhagi camelorum due to have lesser BETA, respectively. Since the effects of soil salinity, soil acidity, soil saturation and soil lime percentage were not significant at $95 \%$ level, they were not considered. Hence, gypsum percentage has the most effect on the distribution of this plant. It is suggested these factors to be considered for future cultivation.

The independent variables including soil salinity, soil saturation, soil acidity, gypsum percentage, soil lime percentage, soil subsurface gravel percentage, soil surface gravel percentage, have lesser effect on Tamarix $s p$ due to have lesser BETA, respectively. Since none of them was significant at $95 \%$ level, it is difficult to conclude. It is suggested these factors to be considered for future cultivation.

Study also reveals that independent variables including gypsum percentage, soil acidity, soil subsurface gravel percentage, soil salinity, soil surface gravel percentage, soil lime percentage and soil saturation have lesser effect on Prosopis srephaniana due to have lesser BETA, respectively. Since the effect of soil saturation was not significant at $95 \%$ level, thus gypsum percentage, soil acidity and soil lime percentage have the lesser effect on the distribution of this plant, respectively. It is suggested these factors to be considered for future cultivation.

The independent variables including soil subsurface gravel percentage, soil saturation, soil surface gravel percentage, gypsum percentage, soil salinity, soil lime percentage and soil acidity, have lesser effect on Artemisia siberi due to have lesser BETA, respectively. Since the effects of soil lime percentage, gypsum percentage, soil salinity, soil surface gravel percentage and soil acidity were not significant at $95 \%$ level, thus soil subsurface gravel percentage and soil saturation have the less effect on distribution of plant, respectively. It is suggested these factors to be considered for future cultivation.

Study also reveals that independent variables including 
Reyhan and Amiraslani: Vegetation and Physico-Chemical Properties of Soil

soil lime percentage, soil acidity, soil salinity and gypsum percentage, have lesser effect on Salsola spp due to have lesser BETA, respectively. Since the effect of soil saturation, soil subsurface gravel percentage, soil surface gravel percentage, soil acidity and gypsum percentage were not significant at $95 \%$ level, thus only soil lime percentage has the effect on the distribution of this plant. It is suggested this factor to be considered for future cultivation.

Conclusion: Many studies have been done to reveal the relationship between soil and vegetation. For example, Dezzeo et al studied the soil properties and vegetation characteristics in southern Venezuela. They showed the differences among the vegetation type based on the existence of organic matters in the soil (Dezzeo et al., 2004).

In Iran, Toranjzar studied the effects of ecological factors on vegetation changes and distribution (Toranjzar, 2004). He showed that soil factors had significant effects on vegetation. In that study, organic matter, sand percentage and $\mathrm{EC}$ had the most effects.

Most parts of Iran have been covered by arid and semiarid areas. In these areas, many soil variables are more or less the same. Most of these soils content soil surface gravel, lime, gypsum etc. In these soils, other factors including acidity and salinity are of importance. Tabas is a degraded area in central part of Iran. In this area, four soil types were distinguished which according to the USDA soil taxonomy, they are classified as Aridisols.

This case studied also focused on the some soil factors (soil surface gravel percentage, soil saturation, soil lime percentage, soil acidity, soil salinity and gypsum percentage) as variables and their effects on the growth of some plant species (Seidlitzia rosmarinus, Haloxylon aphylum, Alhagi camelorum, Tamarix sp, Prosopis srephaniana, Artemisia siberi, Salsola spp).
Generally, in other similar areas like Tabas, these plant species are recommended which show resistant behaviors to such harsh conditions. More efforts should be done to realize other aspects of relationship between soil factors and plants.

\section{Acknowledgement}

Hereby, I sincerely thank International Research Center for Living with Deserts and Khorasan Watershed Management Center for their kind assistance in providing computers and laboratory facilities.

\section{References}

Abrishami, H.M., 1996. The application of regression analysis, Tehran University.

Dezzeo, N., N. Chacon, E. Sanoja and G. Picon, 2004. Changes in soil properties and vegetation characteristics along a forest-savana gradient in southern Venezuela, Forest Ecology and Management, 200: 183-193.

Khajeh, N.A., 1995. Research method, Tehran University.

Pourmirza, A., 1994. Agricultural experimental plans. Uromieh Jihad Daneshgahi Publication Center.

Tehranian, M.S., 1980. The principles of Statistical Methods, Mashad University.

Toranjzar, H., 2004. The study of ecological factors on vegetation distribution of Veshno rangelands, Qom Province, Iran, MSc thesis, University of Tehran.

Zali, A. and S.J. Jafari, 1986. Introduction to statistics and probability, Tehran University.

Zarinkafsh, M., 1987. Applied Pedology. Tehran University. 